\title{
Internal Control Information Disclosure Quality, Agency Cost and Earnings Management-Based on the Empirical Data from 2011 to 2013
}

\author{
Yunchao Ying \\ School of Economics, Jinan University, Guangzhou, China \\ Email: yingyunchao@hotmail.com
}

Received 29 December 2015; accepted 22 January 2016; published 25 January 2016

Copyright (C) 2016 by author and Scientific Research Publishing Inc.

This work is licensed under the Creative Commons Attribution International License (CC BY).

http://creativecommons.org/licenses/by/4.0/

(c) (i) Open Access

\begin{abstract}
Internal control information disclosure is a key factor to investors' decisions, and is closely connected with corporate governance. It also has a direct impact on agency cost and earnings management. This article verifies the relationship between internal control information disclosure, agency cost and earnings management with the Shenzhen A-share listed companies from 2011 to 2013 as samples, and we build the internal control information disclosure index (ICIDI) to evaluate the quality of internal control information disclosure based on the Standard for Enterprise Internal Control. By analyzing, we found that internal control information disclosure can affect earnings management through agency cost, and the improvement of internal control information disclosure will effectively reduce agency cost, thus reducing earnings management.
\end{abstract}

\section{Keywords}

Internal Control Information Disclosure, Agency Cost, Earnings Management, Information Disclosure Index

\section{Introduction}

Information disclosure of internal control is an important channel for investors to obtain accounting information of listed companies. Internal control information disclosure quality of listed companies determines whether companies are worth to invest or not, and the quality of accounting information disclosure directly affects the efficiency of the capital market asymmetry and resource allocation.

How to cite this paper: Ying, Y.C. (2016) Internal Control Information Disclosure Quality, Agency Cost and Earnings Management-Based on the Empirical Data from 2011 to 2013. Modern Economy, 7, 64-70. 
Thus, in the above context, it is necessary to measure the listed company's internal control information disclosure and examine relevant economic consequences.

However, in China, there's few empirical evidence to verify whether the improvement of internal control information disclosure reduces the earnings management by reducing the agency cost. Based on the Basic Norms of Internal Control implemented in 2010, this article is based on the Shenzhen A-share listed companies to explore how internal control information disclosure can improve the earnings management, using agency cost as intermediate variables.

\section{Literature Review}

The existing foreign literature research is mainly related to the status and influencing factors of information disclosure. Doyle et al. [1] studies about listed companies with internal control deficiencies between 2002 and 2005, finding that abnormally surplus is always high in those sample companies, and the larger internal control deficiencies, the poorer quality of earnings. Ashbaugh et al. [2] find that companies which of complex operations and standard organizations are more willing to disclose their internal control deficiencies. Sheifer and Vishny [3] find that the agency cost is inversely proportional to the degree of concentration or the presence of large shareholders. Fama and Jensen [4] emphasize that residual control can improve the supervision efficiency. When it comes to earnings management, Warfield et al. [5] studies the relationship between equity structure and earnings management. Cornett et al. [6] find the increase of share ratio of institutional investors and independent directors can weaken the equity incentive effect on earnings management.

In China, research on internal control information disclosure, agency costs and earnings management mostly concentrate on the market reaction, factors and other important corporate governance variables. There's seldom research on the relationship between any two of the three variables. Yang, Y.F. et al. [7] find that the internal control disclosure of information weakens the agency costs significantly. In addition, Zhang, L.P. et al. [8] studies about the impact of internal control disclosure on earnings management. Yu, H.Z. et al. [9] find the conclusion that there was a positive correlation between the internal control information disclosure and earnings information. Xv, L.L. [10] uses companies listed between 2008 and 2010 as samples, and finds the empirical evidence that the improvement of information disclosure of internal control can reduce the degree of earnings management, and compared with the voluntary information disclosure of internal control, the degree of earnings management of listed companies in the condition of mandatory disclosure of internal control is lower. Gong, Y.W. et al. [11] find the conclusion that the more perfect of internal control information disclosure, the lower the agency cost which caused by the managers and shareholders conflicts, besides, the relationships between agency costs and company size, asset-liability ratio, growth and equity concentration are verified.

Based on the literature review and theoretical analysis, the relationship between internal control information disclosure and earnings management is inconsistent due to the different samples and time. This article uses the data after year 2010, and constructs a panel data model based on hypotheses of three variables to further examine the empirical relationship between internal control information disclosure quality and earnings management.

\section{Research Design}

\subsection{Research Hypothesis}

Based on principal-agent theory and information asymmetry theory, the listed company's internal control disclosure of information is an important way for shareholders to check the fulfillment of management responsibilities, companies with weaker internal controls may lack a sound system and efficient diligent staff, therefore, costs and benefits can't be reliably measured, and it's more probably for managers to make financial information fraud. So we put forward the following assumption:

- Assumption 1: Internal control information disclosure is negative to earnings management.

When the target is inconsistent between managers and shareholders, managers may use information superiority according to their own interests and needs whitewash convey information to shareholders. And the more conflicts of managers and shareholders, the more prone to moral hazard. We put forward the following assumption:

- Assumption 2: Agency costs and earnings management positively correlated.

According to the theoretical analysis above, the agency mechanism and information asymmetry conveniently 
generate the agency costs and earnings management, if the principal-agent conflict can be eased, the agency costs that the eased conflict brings down can help improve the management level of earnings management. Thus, high quality internal control information disclosure is one of the best ways to solve the problem of asymmetric information of listed companies, which can ease the conflict of interest and directly reduce agency cost. Besides, the earnings management is a behavioral consequence of agency costs between shareholders and management, so we have reason to believe that the improving quality of internal control information disclosure reduces the earnings management by reducing agency costs. We put forward the last assumption:

- Assumption 3:

Internal control information disclosure impact the earnings management by agency costs, and the improving quality of internal control information disclosure can reduce agency costs, thus reducing earnings management.

\subsection{Samples and Variables}

Based on the Internal Control Standards (hereafter referred to as the basic norms) implemented formally in 2010, this article choose the A-share listed companies in Shenzhen board from 2011 to 2013 as samples, excluding the financial and insurance industry, the missing data samples and companies listed after 2007 (due to the basic norms was drafted in 2008, companies listed after 2007 have instable impact), receive a total of 1362 observations which constitute a balanced panel data. In this paper, the data of earnings management, agency costs and control variables are from CSMAR database, internal control information disclosure data of listed companies is collected by hand through reading Cninfo annual report, evaluated according to the self-evaluation report about internal control, audit reports about internal control, opinions of independent directors and board of supervisors on internal control of listed companies. The data processing uses Stata 12.0.

\subsubsection{The Measurement of Earnings Management}

Earnings management is management authorities to maximize their self-interest by control and change the accounting information which reported outside on the basis of accounting standards.

According to Su D.W., this article uses the modified Jones model to evaluate the earnings management of listed company $i$ in year $t$, which means to use the ratio that discretionary accruals to total assets (referred to as $\left.D A_{i, t}\right)$. Jones departs total accruals $\left(T A C C_{i, t}\right)$ from discretionary accruals $\left(D A C C_{i, t}\right)$ and non-discretionary accruals $\left(N D A C C_{i, t}\right)$.

Firstly, calculating the total accruals of firm $i$ :

$T A C C_{i, t}=$ net income of year $i\left(N I_{i, t}\right)$ - operating cash flow of year $i\left(O C F_{i, t}\right)$.

Then collecting the total asset of firm $i$ in year $t\left(T A_{i, t}\right)$, changes of sales revenue $\left(G R E V_{i, t}\right)$, changes of receivables $\left(G R E C_{i, t}\right)$ and total fixed assets $\left(P P E_{i, t}\right)$, and estimates the coefficient $\beta_{1}, \beta_{2}$ and $\beta_{3}$ by using least square estimation in following models:

$$
\frac{T A C C_{i}}{T A_{i, t-1}}=\beta_{1} \times \frac{1}{T A_{i, t-1}}+\beta_{2} \times \frac{G R E V_{i, t}-G R E C_{i, t}}{T A_{i, t-1}}+\beta_{3} \times \frac{P P E_{i, t}}{T A_{i, t-1}}+\mu_{i, j} .
$$

The estimated $\beta_{1}, \beta_{2}$ and $\beta_{3}$ are used to calculate non-discretionary accruals $\left(N D A_{i, t}\right)$ :

$$
N D A_{i, t}=\frac{N D A C C_{i, t}}{T A_{i, t-1}}=\hat{\beta}_{1} \times \frac{1}{T A_{i, t-1}}+\hat{\beta}_{2} \times \frac{G R E V_{i, t}-G R E C_{i, t}}{T A_{i, t-1}}+\hat{\beta}_{3} \times \frac{P P E_{i, t}}{T A_{i, t-1}} .
$$

The estimated $N D A_{i, t}$ is used to calculate the discretionary accruals $\left(D A_{i, t}\right)$ :

$$
D A_{i, t}=\frac{T A C C_{i, t}}{T A_{i, t-1}}-N D A_{i, t} .
$$

Finally, this article regards the absolute value of discretionary accruals as the estimation of earnings management (|DA|).

\subsubsection{Construction of Internal Control Information Disclosure Index}

Referring to Yang Y.F. [7], this article measures the quality of internal control information disclosure by constructing internal control information disclosure index (ICIDI for short). Specific content and assignments are described in Table 1. 
Table 1. Internal control information disclosure index.

\begin{tabular}{|c|c|c|}
\hline $\begin{array}{l}\text { First class } \\
\text { indicator }\end{array}$ & Second class indicator & Index assignment instructions \\
\hline \multirow{4}{*}{ Reliability } & $\begin{array}{l}\text { Whether to disclose the CPA audit opinion on internal } \\
\text { controls }\end{array}$ & $\begin{array}{l}\text { No disclosure }=1 \text {, yes but not in detail }=3 \text {, detailed } \\
\text { disclosure }=5\end{array}$ \\
\hline & CPA audit opinion on the financial statements & $\begin{array}{l}\text { Standard and unqualified }=5 \text {, unqualified with } \\
\text { significant matters }=4 \text {, qualified report }=3 \text {, } \\
\text { Inexpressible opinions }=2 \text {, negative opinions }=1\end{array}$ \\
\hline & $\begin{array}{l}\text { Whether board of directors or management have } \\
\text { statement on internal control report of authenticity }\end{array}$ & Yes $=5$, no $=1$ \\
\hline & $\begin{array}{l}\text { Whether the accounting firm hired by companies change } \\
\text { compared with last year }\end{array}$ & No $=5$, yes $=1$ \\
\hline \multirow{4}{*}{ Correlation } & $\begin{array}{l}\text { The number of days from the date of annual report } \\
\text { disclosure to the deadline }\end{array}$ & $\begin{array}{l}\text { Use the method of equal interval assignment, the } \\
\text { earliest }=5 \text {, followed } 4,3,2,1\end{array}$ \\
\hline & $\begin{array}{l}\text { There is not enough evidence to show the existence of } \\
\text { internal control deficiencies of companies }\end{array}$ & Yes $=5$, no $=1$ \\
\hline & $\begin{array}{l}\text { Is there any future plan of internal control construction } \\
\text { problems and rectification plan? }\end{array}$ & $\begin{array}{l}\text { Yes and detailed }=5 \text {, yes but not in detail }=3 \text {, not at } \\
\text { all }=1\end{array}$ \\
\hline & $\begin{array}{l}\text { Is there any important activity to establish and improve } \\
\text { internal controls carried out this year? }\end{array}$ & $\begin{array}{l}\text { Yes and detailed }=5 \text {, yes but not in detail }=3 \text {, not at } \\
\text { all }=1\end{array}$ \\
\hline \multirow{10}{*}{ Integrity } & Ratio of independent directors & $\begin{array}{l}\text { Use the method of equal interval assignment, the } \\
\text { biggest }=5 \text {, followed } 4,3,2,1\end{array}$ \\
\hline & $\begin{array}{l}\text { Whether chairman or vice-chairman is also general } \\
\text { manager }\end{array}$ & No $=5$, yes $=1$ \\
\hline & Whether to disclosure the internal control oversight & $\begin{array}{l}\text { Yes and detailed }=5 \text {, yes but not in detail }=3 \text {, not at } \\
\text { all }=1\end{array}$ \\
\hline & Whether to disclosure the environment of internal control & $\begin{array}{l}\text { Yes and detailed }=5 \text {, yes but not in detail }=3 \text {, not at } \\
\text { all }=1\end{array}$ \\
\hline & Whether to disclosure information and communication & $\begin{array}{l}\text { Yes and detailed }=5 \text {, yes but not in detail }=3 \text {, not at } \\
\text { all }=1\end{array}$ \\
\hline & Whether to disclosure risk assessment & $\begin{array}{l}\text { Yes and detailed }=5 \text {, yes but not in detail }=3 \text {, not at } \\
\text { all }=1\end{array}$ \\
\hline & Whether to disclosure control activities & $\begin{array}{l}\text { Yes and detailed }=5 \text {, yes but not in detail }=3 \text {, not at } \\
\text { all }=1\end{array}$ \\
\hline & $\begin{array}{l}\text { The number of shareholders' meeting(both annual and } \\
\text { extraordinary general meeting of shareholders) }\end{array}$ & $\begin{array}{l}\text { Use the method of equal interval assignment, the most } \\
=5 \text {, followed } 4,3,2,1\end{array}$ \\
\hline & Whether to set internal audit department & $\begin{array}{l}\text { Yes and detailed }=5 \text {, yes but not in detail }=3 \text {, not at } \\
\text { all }=1\end{array}$ \\
\hline & Whether to establish the internal control institution & Yes $=5$, no $=1$ \\
\hline & Whether to disclosure in the form of a separate report & Yes $=5$, no $=1$ \\
\hline Understandability & $\begin{array}{l}\text { Whether to use simple, clear graphic description to } \\
\text { interpret relevant terminology and professional } \\
\text { information }\end{array}$ & $\begin{array}{l}\text { Yes and detailed }=5 \text {, yes but not in detail }=3 \text {, not at } \\
\text { all }=1\end{array}$ \\
\hline
\end{tabular}

Summarizing the index score in Table 1 can get the ICIDI of companies, the bigger of the value, the higher quality of internal control information disclosure.

\subsubsection{Construction of Agency Cost}

Agency cost refers to the losses due to the agency problem, and the cost happens in order to solve the agency problem.

In this paper, agency costs generated based on moral hazard of managers, thus, the article uses the rate of overhead expenses (MFR) to measure the agency cost.

\subsubsection{Control Variable}

According to the earnings management papers, this article uses the following variables: 1) company size (SIZE), 2) the ratio of the largest shareholder (SHARE1), 3) the growth of the company (TOBINQ), 4) the growth of 
operating income, 5) capital structure (LEV), 6) the ratio of independent director (ID), 7) whether chairman or vice-chairman is also general manager $(\mathrm{DUAL}=1=\mathrm{Yes})$.

\subsection{Descriptive Statistics}

Table 2 shows that the mean value of ICIDI is 64, which means the information disclosure quality of Shenzhen A-share listed companies is on the overall level of bias, and the basic norms makes certain effect. However, the ICIDI of different companies are vary widely, maybe because of the basic norms haven't been implemented for a very long time. The mean value of $|\mathrm{DA}|$ is 0.4981 , the degree of earnings management of samples is not so big on the average, but the standard deviation is big, which means the degree of sample companies is vary widely.

\subsection{Correlation Analysis}

Table 3 shows, the maximum of Person is 0.3209 , the minimum is 0.0043 , the absolute value of correlation coefficient between the interpretation of the model variables are less than 0.4 , which means there's no serious multiple correlation between the variables.

\section{Model Design and the Regression Analysis}

\subsection{Regression Equation}

Model 1: the model to verify internal control information disclosure and earnings management

$$
|D A|_{i, t}=\mu_{i}+\alpha_{1} I C I D I_{i, t}+\alpha_{2} S_{H A R E 1_{i, t}}+\alpha_{3} D U A L_{i, t}+\alpha_{4} L E V_{i, t}+\alpha_{5} \mathrm{GROWTH}_{i, t}+\alpha_{6} \operatorname{SIZE}_{i, t}+\alpha_{7} I D_{i, t}+\sum Y E A R+\varepsilon_{i, t} .
$$

Model 2: the model to verify agency costs and earnings management

$$
|D A|_{i, t}=\mu_{i}+\beta_{1} M F R_{i, t}+\beta_{2} S H A R E 1_{i, t}+\beta_{3} D U A L_{i, t}+\beta_{4} L E V_{i, t}+\beta_{5} G R O W T H_{i, t}+\beta_{6} S I Z E_{i, t}+\beta_{7} I D_{i, t}+\sum Y E A R+\varepsilon_{i, t} .
$$

\begin{tabular}{|c|c|c|c|c|c|c|}
\hline Variables & Sample size & Mean value & Standard deviation & Median & Minimum & Maximum \\
\hline$|\mathrm{DA}|$ & 1362 & 0.4981 & 1.2219 & 0.1351 & 0.0000 & 23.2545 \\
\hline ICIDI & 1362 & 65.6792 & 10.4787 & 64 & 18 & 88 \\
\hline SIZE & 1362 & 21.9987 & 1.4766 & 22.0093 & 15.5772 & 26.8954 \\
\hline SHARE1 & 1362 & 0.3411 & 0.1621 & 0.30000 & 0.0360 & 0.8941 \\
\hline TOBINQ & 1362 & 2.6556 & 11.4766 & 1.3921 & 0.6837 & 259.1459 \\
\hline GROWTH & 1362 & 12.6995 & 403.7548 & 0.0820 & -1.0611 & 14883.06 \\
\hline LEV & 1362 & 0.5919 & 0.7160 & 0.5466 & -0.1947 & 13.3969 \\
\hline DUAL & 1362 & 1.8204 & 0.3840 & 2 & 1 & 2 \\
\hline ID & 1362 & 0.3711 & 0.0568 & 0.3333 & 0.1818 & 0.7143 \\
\hline
\end{tabular}

Table 2. Descriptive statistics of variables.

\begin{tabular}{|c|c|c|c|c|c|c|c|c|c|}
\hline & ICIDI & MFR & SIZE & SHARE1 & TOBINQ & GROWTH & DUAL & ID & LEV \\
\hline ICIDI & 1.0000 & & & & & & & & \\
\hline MFR & $-0.1017^{* * *}$ & 1.0000 & & & & & & & \\
\hline SIZE & $0.1165^{* * *}$ & $-0.1155^{* * *}$ & 1.0000 & & & & & & \\
\hline SHARE1 & 0.0348 & -0.0388 & $0.2902^{* * *}$ & 1.0000 & & & & & \\
\hline TOBINQ & $-0.0553^{* *}$ & 0.0329 & $-0.3209^{* * *}$ & $-0.0689^{* *}$ & 1.0000 & & & & \\
\hline GROWTH & $-0.0754^{* * *}$ & -0.0023 & 0.0428 & -0.0179 & -0.0033 & 1.0000 & & & \\
\hline DUAL & 0.0353 & $-0.0605^{* *}$ & $0.1238^{* * *}$ & $0.1577^{* * *}$ & -0.0223 & $-0.0576^{* *}$ & 1.0000 & & \\
\hline ID & 0.0204 & 0.0215 & 0.0229 & 0.0043 & 0.0406 & -0.0202 & $-0.0887^{* * *}$ & 1.0000 & \\
\hline LEV & $-0.0481^{*}$ & 0.0264 & $-0.1046^{* * *}$ & $-0.0442^{*}$ & 0.0183 & 0.0105 & -0.0221 & 0.0170 & 1.0000 \\
\hline
\end{tabular}

Table 3. Pearson correlation coefficients.

${ }^{* * * *}$ Means the significance level $=0.01,{ }^{* *}$ Means the significance level $=0.05,{ }^{*}$ Means the significance level $=0.1$. 
Model 3: the model to verify whether internal control information disclosure impact earnings management by impacting agency costs

$$
\operatorname{MFR}_{i, t}=\mu_{i}+\gamma_{1} \operatorname{ICIDI}_{i, t}+\gamma_{2} \operatorname{SHARE1}_{i, t}+\gamma_{3} D U A L_{i, t}+\gamma 4 L E V i, t+\gamma_{5} \operatorname{TOBINQ}_{i, t}+\gamma_{6} \operatorname{SIZE}_{i, t}+\gamma_{7} I_{i, t}+\sum Y E A R+\varepsilon_{i, t} .
$$

Then, this article estimates agency cost which affected by internal control information disclosure as follows:

$$
M F R P_{i, t}=\hat{\eta} \times I C I D I_{i, t} .
$$

$\hat{\eta}$ is the estimate from the equation of ICIDI, and then make the following equation:

$$
|D A|_{i, t}=\mu_{i}+\phi_{1} M_{F R P_{i, t}}+\phi_{2} S H A R E 1_{i, t}+\phi_{3} D U A L_{i, t}+\phi_{4} L E V_{i, t}+\phi_{5} G R O W T H_{i, t}+\phi_{6} S I Z E_{i, t}+\phi_{7} I D_{i, t}+\sum Y E A R+\varepsilon_{i, t} .
$$

\subsection{Regression Analysis}

Table 4 shows that the whole model has statistical significance. In model 1, the coefficient of ICIDI is negative at the $1 \%$ significance level, which means the higher quality of internal control information disclosure, the lower of earnings management. In model 2, the coefficient of MFR is positive at the $1 \%$ significance level, which means agency costs are positive to earnings management. In model 3, MFR is negative to ICIDI, which means the improvement of internal control information disclosure brings the decline of agency costs. And the fitted value MFRP is positive at the $1 \%$ significance level, which means the improvement of internal control information disclosure will decrease agency cost, and then reduce earnings management, which verifies assumption 3.

\section{Conclusions and Limitation}

This article verifies the relationship of internal control information disclosure, agency costs and earnings management by selecting listed companies from 2011 to 2013 in Shenzhen A-share. Conclusions are as follows:

- The quality of internal control information disclosure is negatively related to the degree of earnings management; the high quality of internal control information disclosure has a significant inhibitory effect on earnings management.

- Agency costs and earnings management are positively related; the degree of earnings management can de-

\begin{tabular}{|c|c|c|c|c|}
\hline \multirow{2}{*}{ Dependent } & \multirow{2}{*}{$\begin{array}{c}\text { Model } 1 \\
|\mathrm{DA}|\end{array}$} & \multirow{2}{*}{$\begin{array}{c}\text { Model } 2 \\
|\mathrm{DA}|\end{array}$} & \multicolumn{2}{|c|}{ Model 3} \\
\hline & & & MFR & $|\mathrm{DA}|$ \\
\hline (Constant) & 2.7947 (1.7571) & $-4.4915^{* *}(1.8723)$ & $26.5292^{* * *}(4.3585)$ & 2.7947 (1.7571) \\
\hline ICIDI & $-0.0416^{* * *}(0.0031)$ & & $-0.0116^{*}(0.0062)$ & \\
\hline MFR & & $0.2208^{* * *}(0.0164)$ & & \\
\hline MFRP & & & & $3.5713^{* * *}(0.2625)$ \\
\hline SHARE1 & $0.4242(0.7667)$ & $0.3869(0.7727)$ & 2.4254 (1.5623) & $0.4242(0.7667)$ \\
\hline DUAL & $-0.3761^{* *}(0.1597)$ & $-0.2788^{*}(0.1621)$ & $-0.6494^{* *}(0.3297)$ & $-0.3761^{* *}(0.1597)$ \\
\hline LEV & $-0.3700^{* * *}(0.0575)$ & $-0.4252^{* * *}(0.0601)$ & $-0.2955^{* *}(0.1278)$ & $-0.3700^{* * *}(0.0575)$ \\
\hline TOBINQ & & & $-0.0714^{* * *}(0.0115)$ & \\
\hline GROWTH & $0.0007^{* * *}(0.0001)$ & $0.0008^{* * *}(0.0001)$ & & $0.0007^{* * *}(0.0001)$ \\
\hline SIZE & $0.0520(0.0767)$ & $0.2386^{* * *}(0.0826)$ & $-1.1158^{* * *}(0.1889)$ & $0.0520(0.0767)$ \\
\hline ID & $-0.4918(1.1321)$ & $0.0713(1.1330)$ & $-0.5060(2.2936)$ & $-0.4918(1.1321)$ \\
\hline YEAR & Yes & Yes & Yes & Yes \\
\hline Adjusted $\mathrm{R}^{2}$ & 0.3085 & 0.2365 & 0.0648 & 0.3085 \\
\hline F value & $80.94^{* * *}$ & $80.47^{* * *}$ & $6.69^{* * *}$ & $80.94^{* * *}$ \\
\hline
\end{tabular}
crease as agency costs fall.

\section{Table 4. Analysis of fixed effect model.}

${ }^{* * *}$ Means significance level $=0.01,{ }^{* *}$ Means significance level $=0.05,{ }^{*}$ Means significance level $=0.1$, all standard error of regression coefficient is through cluster process. 
- Internal control information disclosure affects earnings management by agency cost, and the improvement of disclosure quality can reduce agency costs, thereby reducing earnings management.

In summarize, the implementation of the Basic Norms of Internal Control has an effective impact in our country. Listed companies should improve internal control information disclosure quality to strengthen the reliability of public information and protect the interests of investors.

There are also limitations in this article. Some subjective factors influence the construction and calculation of internal control information disclosure index, which means that the reliability of ICIDI index needs to be verified. Besides, the basic norms have implemented not for a very long time; this article only chooses samples just for three years, and follow-up studies can increase time span to improve the reliability of the conclusion.

\section{References}

[1] Doyle, J.T., Ge, W. and McVay, S. (2007) Accruals Quality and Internal Control over Financial Reporting. The Accounting Review, 82, 1141-1170. http://dx.doi.org/10.2308/accr.2007.82.5.1141

[2] Ashbaugh-Skaife, H., Collins, D.W., Kinney Jr., W.R., et al. (2008) The Effect of SOX Internal Control Deficiencies and Their Remediation on Accrual Quality. The Accounting Review, 83, 217-250. http://dx.doi.org/10.2308/accr.2008.83.1.217

[3] Shleifer, A. and Vishny, R.W. (1997) A Survey of Corporate Governance. The Journal of Finance, 52, 737-783. http://dx.doi.org/10.1111/j.1540-6261.1997.tb04820.x

[4] Fama, E.F. and Jensen, M.C. (1983) Agency Problems and Residual Claims. General Information, 26, 327-349. http://dx.doi.org/10.1086/467038

[5] Warfield, T.D., Wild, J.J. and Wild, K.L. (1995) Managerial Ownership, Accounting Choices, and Informativeness of Earnings. Journal of Accounting and Economics, 20, 61-91. http://dx.doi.org/10.1016/0165-4101(94)00393-J

[6] Cornett, M.M., Marcus, A.J. and Tehranian, H. (2008) Corporate Governance and Pay-for-Performance: The Impact of Earnings Management. Journal of Financial Economics, 87, 357-373. http://dx.doi.org/10.1016/j.jfineco.2007.03.003

[7] Yang, Y.F. (2010) The Relationship between Internal Control Information Disclosure and Agency Cost. Auditing Research, 1, 82-88.

[8] Zhang, L.P. (2010) The Influence about Internal Control to the Earnings Quality. Auditing Research, 2, 83-90.

[9] Yu, H.Z. (2013) Internal Control Information Disclosure, Market Assessment and Earnings Management. Auditing Research, 5, 87-95.

[10] Xv, L.L. (2014) Internal Control Disclosure of Information on the Impact of Earnings Management Research, Empirical Evidence Based on Domestic and Overseas Listed Companies at the Same Time. Hebei University of Economics and Business.

[11] Gong, Y.W. (2015) Internal Control Disclosure of Information to the Agency Cost Impact Study. Communication of Finance and Accounting, 11, 1-6. 